\title{
【特 集：持続可能な廃棄物最終処分場のあり方一埋立研究部会特集一】
}

\section{埋立物制御技術としての中間処理}

\author{
山田正人*
}

【要 旨】 日本と世界の都市ごみと建設廃棄物に対する埋立物の質制御技術について概観した。都市ご みからの有機物低減技術として, 日本の焼却技術に対して, 欧州では機械選別と生物処理を組み合わせ た MBT (Mechanical Biological Treatment) の導入が進められている。また, アジアの都市ごみ処理に 抢ける中間処理では，焼却主体と焼却・生物処理併用の 2 つの流れがある。建設混合廃棄物の破砕選別 処理は, 埋立物から有機物を取り除くだけではなく, 再生利用される資源を分離している。ふるい選別 残さの質制御が技術的課題であり，技術がもたらす費用対効果を考慮する必要がある。地域の事情にあ わせた可変性と経済性を高めることが, 日本の中間処理技術の普遍化に必要である。

キーワード：埋立物，中間処理，有機物，建設廃棄物

\section{1. は じめに}

「中間処理」は日本では普通に用いる用語である。英 訳では “interim disposal” や “intermediate treatment” などの語が当てられるが, これらの語は海外の廃衰物に 関する文献ではほとんど見かけない（なお, “interim disposal” は核廃棄物の地上での一時保管や処分という 意味で用いられるようである)。処分場に埋め立てる前 の廃棄物に手を加えるという行為は, 日本の常識・世界 の非常識であったことが同える。都市ごみにおいてもコ ストが重視される欧米では, 日本における産業廃棄物と 同様に, 最も安価な処分の方法である埋め立てが選択さ れやすい。しかし, 近年の環境政策の厳格化と国際化は 埋立処分コストを上昇させ，埋立量削減と資源回収を担 う中間処理の役割が大きくなりつつある。本稿では, 日 本と世界の都市ごみと建設廃棄物に対する埋立物の質制 御技術について概観する。

\section{2. 都市ごみにおける生分解性有機物の制御}

廃棄物管理の始まりは, 市中のごみを速やかに収集し,

原稿受付 2009. 11. 11

* 独国立環境研究所 循環型社会・廃棄物研究センター 連絡先：テ 305-8506 茨城県つくば市小野川 16-2

E-mail :myamada@nies.go.jp
決められた場所に運んで, 野積みまたは埋め立てること である。開国以来, 埋立地の用地不足と衛生問題に悩ま されてきた日本では, 比較的早い時期から腐敗物の無害 化と減容効果が大きい焼却処理が導入され ${ }^{1)}$, 排出源分 別とともに埋立前に行う都市ごみの一般的な処理方式と なった。同じように都市ごみ処理に焼却を導入している のは, スイスのような小国, パリのような大都市, 熱需 要が大きいデンマークのような寒冷な国であり ${ }^{21}, つ い$ 最近まで世界の都市ごみ処理の趨勢は無処理での直接埋 立であった。

生ごみ等の生分解性有機物が捨てられた埋立地からは 可燃性のガスと污濁した浸出水が発生する。わが国では, 雨水浸透による洗い出し, 底部遮水工と受動的大気導入 を組み合わせた準好気性埋立が対策技術であったが，欧 米では, 埋立地の底部と表面を遮断して雨水の浸入と浸 出水の生成を防ぎ，発生ガスを燃焼または回収利用する Dry Tomb（乾いた墓場）型の技術”を発達させてきた。 しかし, この方式では, 有機物の分解速度が遅く, 30 年という埋立終了後の維持管理期間 ${ }^{3,4}$ 内には, 浸出水 水質や埋立地ガス発生量が基準值までに低下しない。ま た，長期にわたって発生する埋立地ガス（メタンガス） が温室効果ガスであり, 廃棄物からの資源の循環利用が 求められていることから, 欧州（特にドイッ）では 1990 年代より, 都市ごみを埋立前に処理し, 生分解性 有機物の埋立量を削減して, 元を断つという方向に政策 を転換させた ${ }^{3,6)}$ 。 
MBT (Mechanical Biological Treatment, 機械生物処 理) (図 1) ${ }^{6)}$ は,この目的のため開発された中間処理技 術であり，機械選別と好気性・嫌気性生物処理を組み合 わせて，混合ごみより金属 (再利用), 可燃物 (燃料利 用)，生物処理残椬（主に埋め立て）を取り出すもので ある。この技術は，(資源ごみ以外の）分別収集を行わ ず，高コストや污染回避のため焼却が忌避される欧州に おける，本格的な中間処理技術導入の始まりといえる。 なお，ドイツにおけるクラス I埋立地（日本では管理型 に相当する）での有機物に対する受入基準は，通常は TOC が乾燥重量の $3 \%$ 以下（熱灼減量が5\%以下）であ るのに対して, MBT 残椬に対しては $18 \%$ 以下と高めに 設定されている ${ }^{7)}$ 。

埋立地を改善するために埋立ごみの生分解性有機物を 制御することは, 可燃・不燃ごみの排出源分別と焼却処 理が普及した日本では忘れかけている視点である。しか し, 国際的な循環型社会の形成や地球温暖化防止のため に要請が高まりつつある途上国への技術協力では，混合 収集で焼却ができないという現地事情は一般的である。 図 2 にアジアにおける有価物を除いた都市ごみストリー ムを, 排出量に対して埋立, 焼却および生物処理（堆肥 化等）される割合で示す ${ }^{8)}$ 。焼却主体のシステムである 日本やシンガポール等の Type IVに対して, 欧州と同様 に食品廃棄物の直接埋立を禁止した韓国では近年, 生物 処理と焼却を併用する Type IIIのシステムを採用した。 中間処理の導入が始まった Type IIの国においても，生 物処理主体で始まったインドネシアと焼却主体で始まっ た中国と進む方向は多様である。
欧州は既に以上のアジアを含めた途上国において MBT の導入を進めている。日本は 1970 年代に「スター ダスト 80 計画」において類似の技術開発を行い, 混合 ごみの機械選別には限界があることを認識し，排出源分 別重視へとシフトしていった歴史がある ${ }^{9)}$ 。生分解性有 機物は腐敗する污染物であり，再利用は食料生産と直結 するから，排出から再利用・処分に至るまでの取り扱い には細心の注意を要する。欧米と日本という限定された 風土で発達してきたこれらの技術を, 異なる風土の地域 に適合化させることは，未だ模索すべき研究課題である。

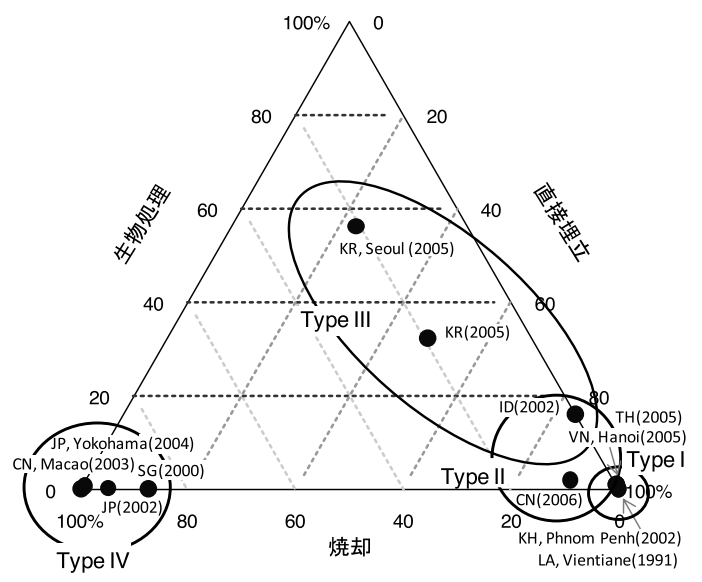

図 2 アジアにおける有価物を除いた都市ごみストリー ム ${ }^{8)}$ (国名は ISO3166-1 alpha-2 による)

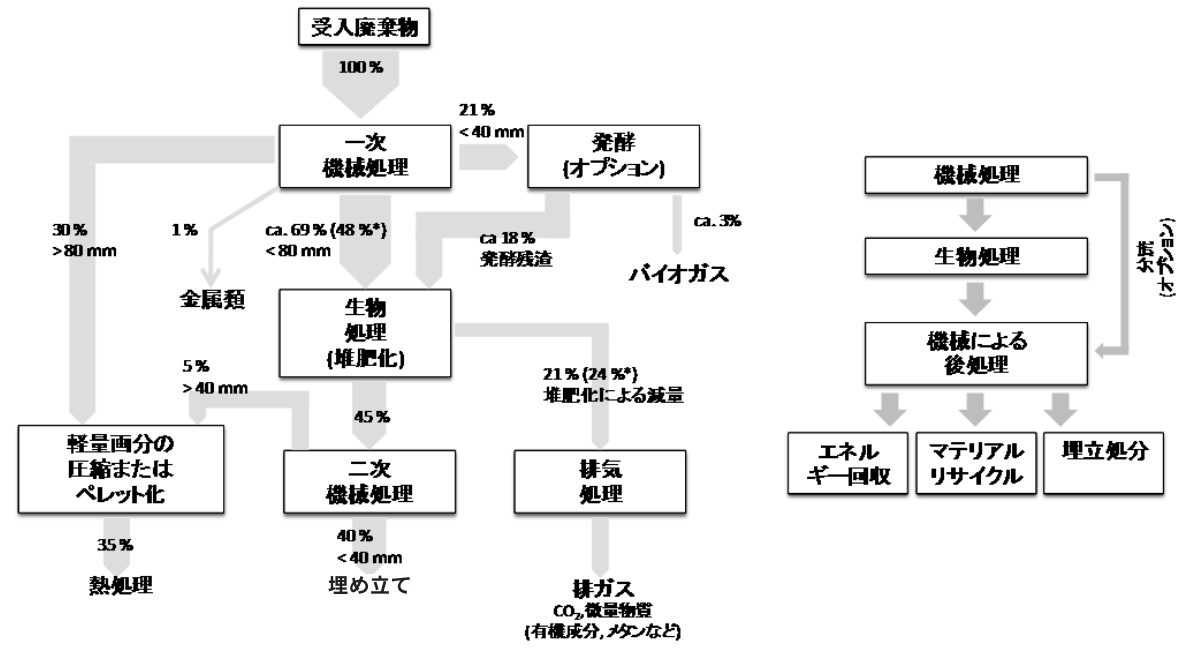

図 1 機械·生物処理 ${ }^{6)}$ (左：物質フロー型処理, 右：機械・生物学的安定化) 


\section{3. 建設廃棄物における破砕選別}

日本に㧍ける都市ごみ（一般廃棄物）の循環・処分シ ステムは分別収集が前提となって組み立てられている。 日本人が利益も与えられずに, 地域によっては 30 品目 以上を家庭で精度高く分別できることは誠に摩訶不思議 であるが，この排出源における「中間処理」が以降の処 理処分を安定させ，新たな技術導入を容易にしているこ とも確かである ${ }^{10)} 。$

産業廃棄物は排出時に性状が一定であることが多く, 再生利用や処理が比較的容易であり，2005 年度の排出 量（4 億 2,000 万 ton）に対する最終処分率は $6 \%$ であ る ${ }^{11)}$ 。埋立処分される割合が高い産業廃棄物の一つとし て建設混合廃棄物がある。2005 年度における建設混合 廃棄物の発生量 (290万 ton) に対する最終処分の割合 は約 $72 \%$ であり, 建設廃棄物全体（発生量 7,700 万 ton）の $8 \%$ と比較して格段に大きい)。建設混合廃棄物 に混在するアスファルト・コンクリート塊, コンクリー 卜塊, 建設発生木材, その他（金属くず, 廃プラスチッ ク類等）の単品としての最終処分率は，それぞれ，1\%, 2\%, 9\%, 29\%であるから ${ }^{12)}$, 混在していることが再利 用や処理 (縮減) を妨げている。また, 見た目はがれき 類であるため, 混在している木くず等の有機物や石膏 ボード等が安定型廃棄物として埋め立てられる恐れがあ る。

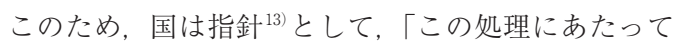
は, 総体として安定型産業廃棄物以外の廃棄物として取
扱い, 中間処理施設, 又は管理型最終処分場において適 切に処理しなければならない」,「なお, 建設混合廃棄物 から安定型産業廃棄物を選別 (手, ふるい, 風力, 磁力, 電気等を用いる方法により）し，熱しゃく減量を $5 \%$ 以 下とした場合, 当該廃棄物は安定型産業廃棄物として取 り扱うことができる」とした。がれき類等の粗大で乾い た建設廃棄物は輸送と最終処分の効率を高めるため, 中 間処理で破砕される。この建設廃棄物の破砕施設は, 指 針に従って安定型廃棄物を峻別する機能を有した「破砕 選別」施設となった。

これら施設に備えられている技術（図 3) では, 先の 指針に示されている技術を用いて廃棄物からがれき類, 廃プラスチック類, 木くず, 土砂等を容姿, 大きさや比

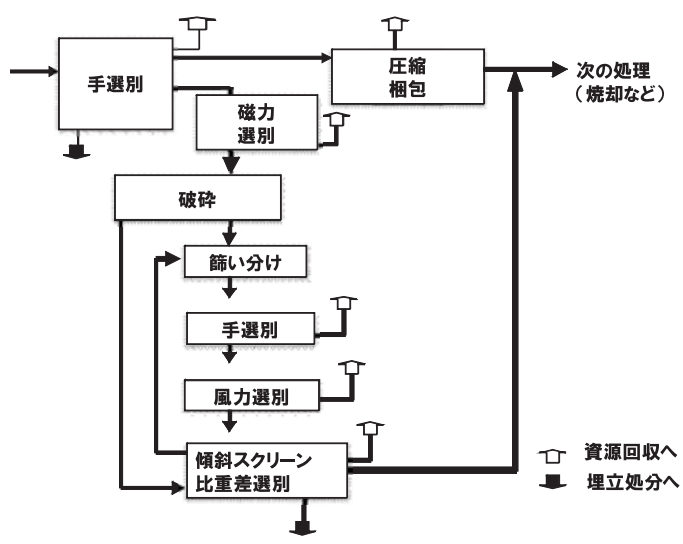

図 3 破砕選別技術

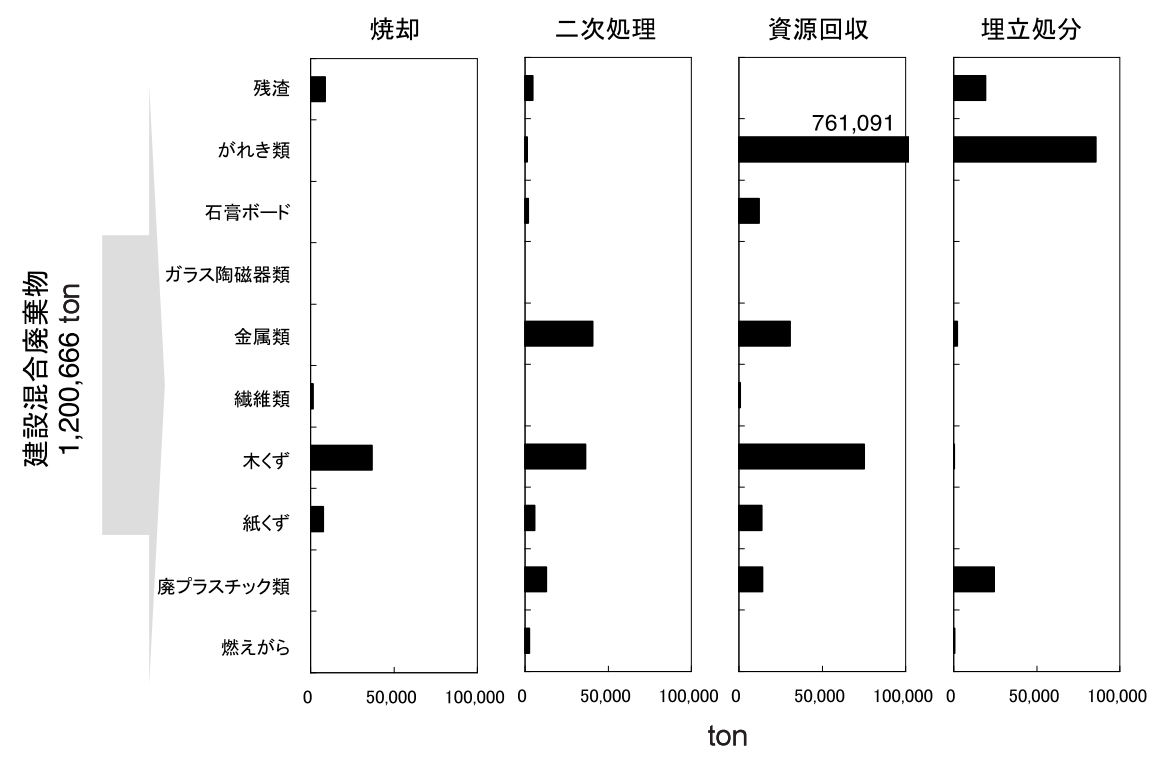

図 4 破砕選別施設における建設混合廃棄物からの各種品目の産出と再生・処分の状況 (埼玉県, 2003 年度) ${ }^{14)}$ 
重差等で分離する。関東圈で建設廃棄物の中間処理施設 が集中する埼玉県での事例を図 4 に示す ${ }^{14)}$ 。実態として, 破砕選別は建設混合廃棄物を夾雑物である可燃物と安定 型廃棄物に分離するだけではなく, 有価物を分離して再 利用に向かわせている。すなわち, 破砕選別施設は廃棄 物と資源のインターフェースを担う循環型社会の拠点に なりつつある。また, ほとんどの産物は再利用され, 分 離後に埋立処分される主な品目は, 再利用できなかった がれき類, 廃プラスチック類とふるい選別後の多品目が 混在する残椬である。したがって, 建設混合廃棄物にお いて埋立地環境を改善するために質を制御すべきものは, これらの品目，特にふるい選別残さである。

Asakura らは, 小粒径のふるい下の残椬の品質につ いて, 熱灼減量の約 8 割は木くず等の有機物ではなく結 合水に起因する ${ }^{15)}$ が, 混在する木くずや石膏は粒径分布 に遍在するため, ふるい選別では除去できないこと胡を 報告している。また, 六価クロムとフッ素の溶出濃度, 鉛の含有量が土壌環境基準を超過する場合があり, 地盤 材としての利用には注意が必要であるとしている ${ }^{16)}$ よって, これらの分離には新たな選別技術を追加する必 要があると考えられる。

しかし, 産業廃衰物は基本的に市場原理で処理・処分 されるものであり, 費用という点では破砕選別も埋立処 分も等価である。また, 同一の廃棄物であっても, 破砕 選別による回収資源の売却益や残椬の処分費, 破砕選別 施設と資源利用・処分先の位置関係（すなわち輸送距 離）が地域によって異なるため, 業として成り立つ破砕 選別のあり方は地域によって異なる。廃棄物を原料とし て活用する需要は急激に増加しているが, 最終処分料金, 特に安定型品目処分費とのコスト差や処理委託費の低価 格化などにより, 資源循環の機能を有する破砕選別技術 が十分に活用されないこともある。破砕選別技術の機能 を強化し, 産業廃棄物の資源循環を持続的なシステムと するためには，新たに導入または改善すべき技術の能力 だけでなく，技術がもたらす費用対効果を厳しく検討す ベきである。

\section{4. おわりに}

日本における中間処理の花形は燒却（または熱処理） であり, 明治の昔から数多の研究開発が行われ, 結果と して国内に数千の実機が存在し, ダイオキシン問題も克 服し, ガス化溶融のようなかつての夢の技術 ${ }^{1)}$ を実現さ せるところまできた。しかし，公共主導で先鋭，均一， 巨大化された技術は, 日本以外の気候, 経済および社会 への適用性を狭め, また同時に, 有機物制御の代替技術
である生物処理の技術力を低下させた感がある。また, 埋立地にとっては絶大な有機物の低減をもたらし, 温室 効果ガス排出源としての課題を始まる前に終わらせた ${ }^{17)}$ が，無機物が濃縮された焼却残椬の安定化という新たな 問題も生じさせた。

破砕選別技術は埋立地に対する規制や循環型社会とい う新たな経済に対応して, 現場で独自に開発された技術 であり，多くは鉱山（選鉱）の技術を援用しているが, 廃棄物へ対応した質変換技術という点では十分に体系化 されていない。また, 闇雲に最新技術がもてはやされる のではなく, 変動する市場に対応した経済性が厳しく追 及される世界である。

ともあれ, 両方とも日本が独自に発展させた世界に誇 る最先端の廃棄物の質制御技術であり, 国内問題対応で 完結させるべきではない。国際化のためのキーワードは おそらく, 多様な状況下における可変性と経済性である。 前者は技術の成り立ちを今一度振り返る歴史学であり, 後者は技術を売り込むマーケティング学である。ともに， 理系の技術者, 研究者には勝手がわからず荷が重い課題 であるが, 日本の技術の普遍化のためには, 避けては通 れない道のように思える。

本稿で取り上げた研究の一部は環境省地球環境研究総 合推進費（B-071）ならびに環境省循環型社会形成推進 科学研究費補助金（K2157）に招ける成果である。

\section{参考文 献}

1) 溝入 茂: ごみの百年史, 学藝書林 (1987)

2) OECD : OECD Environmental Data Compendium 2008 (2008)

3 ) 松藤敏彦, 田中信寿 : 持続可能な埋立地をめざす早期 安定化戦略——欧米における研究のレビューとわが国 の位置付け一一, 廃棄物学会誌, 第 16 巻, 第 1 号, pp. 34-41 (2005)

4) The Council of the European Union: Article 10, In Council Directive 1999/31/EC of 26 April 1999 on the Landfill of Waste (1999)

$5)$ United States Government: Part 258-Criteria for Municipal Solid Waste Landfills, § 258.61 Post-closure Care Requirements (a), In Code of Federal Registration (1992)

6) BMU: Municipal Solid Waste Management in 2006, TASi One Year on - No Wastes Landfilled without Pretreatment in Germany since 1 June 2005 (2006)

7) BMU: Ordinance on Environmentally Compatible Storage of Waste from Human Settlements (Abfallablagerungsverordnung - AbfAblV) of 20 February 2001 (2006)

8) M. Yamada, K. Kawai, T. Ishigaki and M. Osako : Waste 
Stream Diagram and Transition of Waste Management in The World, Sardinia 2007, Twelfth International Waste Management and Landfill Symposium, Cagliari, Italy (2009)

9 ）環境省：第 2 節 循環型社会の歴史, In 平成 20 年度 版環境/循環型社会白書 (2008)

10）山田正人：分別という技術，都市清掃，第 59 号, pp. 311-314 (2006)

11）環境省：産業廃棄物の排出及び処理状況等（平成 17 年 度実績）について, 報道発表資料（平成 20 年 1 月 24 日) (2008)

12）国土交通省：平成 17 年度建設副産物実態調查結果につ いて, 報道発表資料（平成 18 年 12 月 8 日) (2006)

13）環境省：建設工事等から生ずる廃棄物の適正処理につ いて (通知), 環廃産 276 号 (平成 13 年 06 月 01 日) (2001)

14) M. Yamada, H. Asakura, Y. Inoue, Y. Watanabe, Y. Ono and K. Tachio: Role of Intermediate Treatment in
Industrial Solid Waste Stream for Quality Control of Landfilled Waste, Sardinia 2007, Eleventh International Waste Management and Landfill Symposium, Cagliari, Italy (2007)

15) H. Asakura, Y. Watanabe, M. Yamada, Y. Ono and Y. Inoue: Investigation on the Components Removed in Loss on Ignition Test of Sandy Crushed Construction and Demolition Waste, Waste Management \& Research, on line (2009)

16) H. Asakura, Y. Watanabe, M. Yamada, Y. Ono, A. M. Alfaro and Y. Inoue : Characteristics of Fine Processed Construction and Demolition Waste in Japan and Method to Obtain Fines Having Low Gypsum Component and Wood Contents, Waste Management \& Research, on line (2009)

17）山田正人：CDM と廃棄物管理, 都市清掃, 第 60 号, pp. 345-350 (2007)

\title{
Intermediate Treatment as Quality Control Technology for Landfill Waste
}

\author{
Masato Yamada \\ Center for Material Cycles and Waste Management, \\ National Institute for Environmental Studies \\ (16-2 Onogawa, Tsukuba, Ibaraki 305-8506 Japan)
}

\begin{abstract}
Quality control technologies for landfill MSW on a global scale and C\&D waste in Japan were reviewed. A method known as mechanical biological treatment (MBT), which combines mechanical sorting and biological treatments, is being introduced in Europe as a means for developing a technology that will reduce organic materials in MSW. There are two directions MSW disposal can take in Asia : incineration dominant or utilization of combined incineration and biological treatments. The crushing and separation process of mixed C\&D waste not only removes organics from landfill waste, but also recovers secondary resources. A technological issue related to this technology will be quality control of sieved residues. The cost benefits of applicable technologies must also be considered. Improvements in flexibility and economic efficiency for adapting to local situations will be necessary in order to universalize intermediate treatment technologies in Japan.
\end{abstract}

Key words: landfill waste, intermediate treatment, organic materials, construction and demolition 